\title{
SECURITY AND PEACE IN AFGHANISTAN: BEFORE AND AFTER 2014
}

\author{
Abdul-Qayum Mohmand ${ }^{*}$
}

\begin{abstract}
The military campaign of the forces of the United States, NATO and the International Security Assistance Force (ISAF) increases distance between the Afghan opposition, the Karzai government, and the international forces in Afghanistan. Along with this, the failure of the Karzai government to provide security and protect Afghans against the insurgency, provide basic public services, support day-to-day economic activities, and institute urgently needed programs that can provide tangible economic and social results, reduces chances for any foreseeable stability and peace. To overcome these challenges and enable the Afghans to live in peace, security, and prosperity, the invading forces must agree to negotiate with the resistance, towards political compromise and a negotiated settlement, with complete withdrawal of their forces from Afghanistan. Leaving behind even a small contingency of troops would in effect mean the continuation of war. Once negotiations have taken place and agreements have been reached, the United Nations Security Council should mandate the Organisation of Islamic Cooperation (OIC) to send their troops as monitors and peacekeepers to Afghanistan.
\end{abstract}

\section{Introduction}

The strong emphasis of the United States, NATO and ISAF on a military solution, the continuing use of heavy forces in military operations, and the indiscriminate bombardment of houses, villages, funeral processions, wedding ceremonies, and Jirga gatherings are leading to more civilian casualties, anger, and further alienation of the Afghan people. The lack of political and administrative reform, the defective political and unsustainable economic development, and the absence of social justice all gravely undermine the current regime and diminish the chances for peace. These factors create resistance and animosity towards the Karzai government and the Americans and their allies. These also help the Taliban become stronger as every day passes. To address these concerns, establish peace and security, implement political and economic reforms, and include the resistance, especially the Taliban, in the political process with mechanisms for power-sharing, the following needs to be done:

First, recognise that the war in Afghanistan cannot be won by military means. The war can only come to an end through political negotiations and peace settlements. The continued emphasis of the US on war strategy under the 
delusion that the war in Afghanistan may be won by military means has failed for the past eleven years to deliver the desired peace. The United States has signed a strategic partnership agreement with Afghanistan, according to which the United States intends to leave unspecified numbers of American forces in Afghanistan. But to bring an end to the endless war in Afghanistan, the forces of the United States, NATO, and ISAF need to completely withdraw their troops without any preconditions. The presence of small numbers of forces in Afghanistan will be seen as continued occupation and result in the continuation of war.

Second, even though some of the allies of the United States have expressed their willingness to negotiate with the resistance, in the past eleven years no serious efforts have been taken to find venues for such negotiations. The United States hopes that with the passing of time the resistance will be weakened and eventually defeated. But the resistance has proven that it is able to withstand the military campaign of the United States, NATO, and ISAF. Therefore, to establish peace and security and to work toward a political compromise, serious negotiations must be started with the resistance, especially the Taliban, and sooner rather than later. The inclusion of the resistance will stop the bloodshed and enable Afghanistan to concentrate on social and economic development, providing venues for Afghans and international investors to invest in the society and the economy.

Third, the US-Afghanistan Enduring Strategic Partnership Agreement is of great concern to Afghanistan and the neighboring and regional countries. The Agreement is not clear about the United States' objectives in Afghanistan. It does not provide any information about how the United States intends to finance its presence in Afghanistan and support the Afghan security forces and economic development. Countries in the region, along with Afghanistan, are concerned that the United States may launch operations in the region from their bases in Afghanistan. The agreement does not specify who will have the ultimate authority over the use and deployment of American troops and what laws will apply to the American forces in Afghanistan. The neighboring and regional countries are also concerned that the United States will monitor their military activities and development from Afghanistan. The starting point must be the withdrawal of foreign forces from Afghanistan.

\section{Continued Confrontation versus Withdrawal}

Throughout history, Afghanistan's strategic location has attracted many expansionist and imperialist powers. Its geostrategic location made Afghanistan a crossroad of Asia and a battleground of "Great Games". Afghanistan has seen many invasions over the past one hundred and fifty years of Afghanistan's 
history, namely by the Great Britain, the Soviet Union, and the United States and its allies. All occupiers tried to completely occupy the country, win their wars by military means, and subjugate the people, but they all failed. The fate of the current invaders will not be much different than from the previous ones. As David Isby states: "At the end of the day, outsiders - Soviet, British, Arabs, American - will go home or vanish in smoke and the Afghans will be left with what they have always had: their land, their faith, and each other."

In the past eleven years the United States has reiterated that it will win the war and defeat the resistance. This mentality and the emphasis on warfare have forced the United States and its allies to use different war methods and strategies, including chemical weapons and depleted uranium, ${ }^{2}$ but they have remained unable to defeat the resistance or win the war. Not only is the war not won, but the security situation has deteriorated and the resistance has gained more ground. The United States, NATO and ISAF are running out of options to handle the current war and have no plan to deal with the war and the resistance after 2014: "It is unclear that the US and ISAF have effective plans to deal with the political nature of war they are fighting, or credible plans for developing the Afghan National Security Forces (ANSF)." ${ }^{3}$

The multi-dimensional efforts United States and its allies to win the war by military means and bring about stability and peace have failed. They are losing the war both on political and military fronts. On the political front, the United States and its allies have made various attempts to provide legitimacy to the Karzai government by using aid money and appointing advisors and through public relations and propaganda. They have tried to build the Afghan National Army (ANA) and Afghan National Police (ANP), reform the Karzai government, and strengthen the judiciary. Progress in these areas cannot be demonstrated in real terms, despite constant reports issued by the United States and the Karzai government about improving the security sectors, training the judiciary, and cleansing many towns and the countryside of Taliban control. According to the Obama administration's strategy for Afghanistan and Pakistan, The Way Forward in Afghanistan and Pakistan, which was made public on 1 December 2009, the overarching goal of the United States is to disrupt, dismantle, and defeat alQaeda in Afghanistan and Pakistan, reverse the Taliban momentum, and deny them the ability to overthrow the Kabul regime. President Obama stated: "First, we will pursue a military strategy that will break the Taliban's momentum and increase Afghanistan's capacity over the next 18 months. Second, we will work with our partners, the United Nations, and the Afghan people to pursue a more effective civilian strategy, so that the government can take advantage of improved security." 
On-the-ground realities in Afghanistan reveal the opposite. The government remains corrupt, the judiciary is still not functioning, and the Taliban are stronger than ever before in many places, including areas the United States and the Karzai administration claim are fully under their control. The latest attacks on the US Base at the Jalalabad, Nangarhar Airport on 2 December 2012 and on Camp Bastion in Helmand on 14 September 2012 prove that the Taliban have the ability to strike at almost any target they desire. The resistance is intact and very much alive. Even American personnel have had doubts about the effectiveness of American warfare and their support of the Afghan government. Mr. Matthew Hoh, former US Senior Civilian Representative in the Zabul province, confirmed this point in his resignation letter to Ambassador Nancy J. Powell on 10 September 2009. He states: "Like the Soviets, we continue to secure and bolster a failing state, while encouraging an ideology and the system of government unknown and unwanted by its people. . . . The United States military presence in Afghanistan greatly contributes to the legitimacy and strategic message of the Pashtun insurgency. In a like manner our backing of the Afghan government in its current form continues to distance the government from the people." 5

US and NATO troops forcefully enter people's houses without warning and kill innocent people in the process. They imprison innocent people in the name of al-Qaeda and the Taliban. The abuses of the Americans and their allies and the corruption, extortion, and bribery of the ANA and ANP have added to the mistrust and animosity toward foreign troops and the Karzai government. In addition, both the ANA and the ANP disregard the importance of civil institutions and institutional structures, important elements of social progress. "The central government's legitimacy has deteriorated. Sub-national government structure still lacks capacity. In their place, militia commanders and local mafia have filled the void, undermining local governance, democratic rights, and service delivery." All these have undermined efforts to consolidate democratic institutions and to create a pluralistic society.

There are some improvements in areas of education, health care and consumer commodities, but none are sustainable. The Afghans are still in shock and wait for the much-promised assistance from the United States, the Western countries and the international community, but they have lost hope. "There is no clear strategy for Transition in terms of concrete plans, credible resources, and meaningful measures of effectiveness. The US and its allies have failed to show that there is any meaningful path toward even a modest definition of lasting "victory"'? The government is still run by corrupt politicians, warlords, and drug mafia who are only interested in filling their own pockets with the aid money Afghanistan receives to build the infrastructure, the society, and the economy. "The civil efforts lag far behind the military effort. While there have been some successes 
in some aspects of Afghan governance and development, they are so limited and fragile they may well not survive beyond 2015." "As soon as the international aid has ended, the temporary and fragile improvements will likely collapse and disappear.

On the military front, the indiscriminate bombardment of towns and villages and the numerous massacres of innocent Afghans by foreign troops, especially by the Americans, in the past eleven years, have caused disarray, anger, and resentment. To name a few, urinating on Afghan dead bodies, the massacre of 65 innocent women and children in Konar, the killing and burning of children in Konar by the American war machines, the burning of the Qur'an in Bagram, and the latest massacre of 16 Afghan men, women and children in Panjwai add fuel to the conflict and undermine the US objective of winning "the hearts and minds" of the Afghan people. The United States and its allies are not seen as leverage towards peace, but elements adding to the exacerbation of violence and tension in Afghanistan.

After the Afghan people and Hamid Karzai expressed their outrage about the massacre of children in Konar and the subsequent allegations by General David H. Petraeus that the children were burned by their parents, on 2 March 2011, Petraeus accepted responsibility and apologised for the killing of innocent children which resulted from a dual helicopter assault that mistook a group of ten children for insurgents. ${ }^{9}$ One has to ask the question why these mistakes happen repeatedly, and whether this was really another mistake or the children were intentionally massacred. The two planes involved in the attack were Apache helicopters.

The Apache is designed to fight and survive during the day, night and in adverse weather throughout the world. . . . The Apache features a Target Acquisition Designation Sight (TADS) and a Pilot Night Vision Sensor (PNVS) which enables the crew to navigate and conduct precision attacks in day, night, and adverse weather conditions. . . . The Apache has state of the art optics that provide the capability to select from three different target acquisition sensors. These sensors are:

- Day TV. View images during day and low light levels, black and white.

- TADS FLIR. Views thermal images, real world and magnified, during day, night and adverse weather.

- DVO. Views real world, full color, and magnified images during daylight and dusk conditions. ${ }^{10}$

With the precision and sophistication of the Apache technology one is forced to question the "mistake". The repetition of these incidents convinces the 
observer that this may have been intentional killing rather than another mistake. The Afghans are aware of these acts of violence against the civilians and are not accepting them as mistakes and reject this culture of apology. They say that their families are killed first, and then an apology is offered later, but the responsible persons are never brought to justice. "We cannot tolerate this anymore. Our innocent men, women and children are killed every day and the government is not doing anything about it. If the government cannot protect us, we will turn somewhere else." ${ }^{11}$ This way of doing business has created a far greater distance between the average Afghan and the occupying troops.

The ANA and ANP are not in better shape since the United States first began managing the situation in Afghanistan. Due to ethnic imbalance, both in the army and police structure, there is great tension between the different segments of the society. The ANA and ANP forces are not prepared to handle the security situation and are not capable of providing security for and creating harmony among the people. They are poorly trained and ill-equipped to deal with the resistance. If the matter is left to the Afghan army and Afghan police, the Afghans will have to wait for a long time to see peace and security in their war-torn country. In spite of the vacuous claims that came out of largely symbolic conferences in Chicago and Tokyo, there is no public evidence that the US and ISAF have really reversed insurgent momentum in Afghanistan or created conditions where tactical victories will have lasting strategic meaning. ${ }^{12}$ Afghanistan is still warstricken and poor and lies in despair. Furthermore, building a state based solely on a security mechanism will not bring an end to the war. As Stephen Hadley argues: "A transition that focuses primarily on Afghan security force levels and capabilities cannot adequately address the flaws in governance that have alienated Afghans from Karzai administration and fueled the insurgency."13 The United States may be able to build a security state in Kabul, if not in the whole of Afghanistan, but this will bring no peace or stability.

As a last resource to win the war, the United States created new local and tribal militias, but these will pose a grave danger to the future security of Afghanistan. In the war against the resistance the United States still relies on second-hand information, which always leads to a large number of civilian casualties and enormous suffering of innocent people in each attack. The lack of information about the resistance and the mismanagement of the war against them "has led to an over-reliance upon destructive air strikes, leading to increased civilian casualties and lower level support for the Karzai government and the West's presence in the country." 14

The only solution remaining for the occupying forces is a complete and unconditional withdrawal of their troops from Afghanistan. The interminable war in Afghanistan needs to end. "The US cannot plan to defeat the Taliban and 
other insurgent by 2014, or for Afghan government and forces to do so through 2020 . . . The present US and ISAF strategy has failed in its ability to secure the border areas, all critical Districts, and Districts of interest." ${ }^{15}$ The latest reports on developments in the war in Afghanistan indicate that the United States, NATO, and ISAF military operations there are aimless and indecisive and the resistance is gaining more ground than it is losing.

Foreign troops need to stop their military offenses and begin their gradual withdrawal from Afghanistan. Before leaving, these countries need to make sure a viable government is left behind, a government not only representative of the Afghan interests and needs, but one that can provide security to the people. Otherwise the country will fall into civil war, with heavy losses of Afghan lives. An uncoordinated withdrawal will leave Afghanistan as a regional and global hotbed and the center of a new "great game". Two steps are necessary, under the circumstances. First, direct and honest negotiations with the resistance to reach a political settlement. Second, the replacement of the US, NATO, and ISAF troops by OIC forces.

\section{Negotiating with the Resistance Movement}

Both the United States and the resistance are at a critical point in the conflict. The United States is facing economic challenges both at home and abroad and is under pressure to bring the troops home. The resistance on the other hand, especially the Taliban, is desperate to position itself as the dominant player in the political bargaining competition. This would be more feasible if the Taliban would seriously negotiate with the United States and agree on a political settlement., gaining thereby international recognition.

Despite the unprecedented amount of international financial aid and military support to the government of Afghanistan, the increase in the number of US military forces, and the various tactics of the US, NATO, and ISAF to defeat the resistance and establish peace, security, and the rule of law, the situation in Afghanistan has deteriorated and the resistance has grown. War, insurgency, and security in Afghanistan have moved to a new state of affairs. The resistance, especially the Taliban, has expanded attacks and gained territory in the north and the west of Afghanista and become a countrywide movement. Therefore, there are three main reasons why the United State should negotiate with the Taliban.

First, there is a general perception in Afghanistan and in the Afghan Diaspora that the current war in Afghanistan is aimed at Pashtuns to reduce their numbers, their strength, their capacity, and their dignity. Therefore, the initial resistance and attacks by the Taliban alone moved the Afghans, especially the Pashtuns, to resist invading foreign powers. There are not only Pashtuns from Kandahar or Helmand 
or Paktiya or Konar who are fighting foreign troops in Afghanistan, but Afghans and Pashtuns throughout the whole of Afghanistan. Matthew Hoh confirms this resistance by stating that "the Pashtun insurgency, which is composed of multiple, seemingly infinite, local groups, is fed by what is perceived by the Pashtun people as a continued and sustained assault, going back centuries, on Pashtun land, culture, tradition and religion by internal and external enemies. The US and NATO presence and operations in Pashtun valleys and villages, as well as Afghan army and police that are led and composed of non-Pashtun soldiers and police, provide an occupation force against which the insurgency is justified." 16 The degree of resistance, though, differs from province to province, with the south and east being the strongest, but resistance is expanding and has incorporated many areas throughout Afghanistan.

The thinking behind the policy of war against the Pashtuns is that if Pashtuns are reduced in numbers and their political and economic capacities are weakened and/or diminished, the resistance to the international occupying forces will also be weakened and will eventually diminish. The eleven years of war in Afghanistan have proven the opposite. The more that pressure is applied, pain inflicted, their houses and farms destroyed, and their men, women, and children killed, the more they become aware of their situation and lend a supporting hand to the resistance. Therefore, to bring an end to the war and to bring peace and security, the answer is not to prolong the war and weaken the Pashtun capacities. Instead, the United States and its allies need to bring an end to the fighting and agree to a political compromise with the resistance. They need to bring an end to the continuing political and social mischief and military aggression. The Americans and the international community need to embrace a deeper understanding of Afghanistan's social values, economic needs, and political motivations. Failure to recognise these realities will lead to the demise of the US power in Afghanistan. Furthermore, such feelings and understandings of the war strategy in Afghanistan have added additional support for the Taliban. As a result, the Taliban are supported not only by their rank and file, but also by the common man in and outside Afghanistan, the intelligentsia in the country, and the expatriates.

War and resistance in Afghanistan have moved from fighting between the Taliban and the United States and its allies to one of survival, representation, and foreign occupation. Mathew Hoh affirms this again by stating that "the bulk of the insurgency fights not for the white banner of the Taliban, but rather against the presence of foreign soldiers and taxes imposed by an unrepresentative government in Kabul." ${ }^{17}$ Furthermore, "the presence of foreign troops on Afghan soil is almost certainly driving the insurgency." 18 This policy of war will leave bad memories behind and may also lead to a future general objection to foreigners, especially to the Americans by the Afghans. It also has a positive impact on the 
Taliban. It has changed the Taliban movement from a military fighting force to a politically conscious resistance and opposition movement. With this change, the Taliban has transformed from a purely religious militia group of former madrasa students and graduates obsessed with the strict interpretation, application, and understanding of the Shari'a, and restoration of their power, to a group open to inclusion and pluralism, respect and protection of human rights, and acceptance of education for all genders. This is an important change which will influence the future political system of Afghanistan.

Second, the United States is facing great economic challenges both at home and abroad and there is tremendous political pressure on President Barack Obama to bring American men and women back home. The war and occupation of Afghanistan have cost the United States trillions of dollars and tens of thousands of American and Afghan lives. At home, the United States economy is in decline, unemployment is rising, the education system is deteriorating, and the national debt is skyrocketing.

On the political front there is a bipartisan consensus that the United States should end the war and withdraw its troops from Afghanistan sooner rather than later. "Senator Richard Lugar (IN), ranking member of the powerful Senate Foreign Relations Committee, has long expressed doubt about the possibility of success in Afghanistan. Senator John Kerry (MA), chair of the same committee, has questioned the war strategy in the context of how it all will end." ${ }^{19}$ On 10 February 2011 House Representative Woolsey Lynn of California introduced H.R. 651, United States-Afghanistan Status of Force Agreement (SOFA) Act of 2011, which was cosponsored by seventy members of the House. The bill prohibits the United States from having permanent bases and military presence in Afghanistan. Furthermore, it requires the United States government to redeploy American troops in a complete, safe and orderly manner within one year after the agreement is signed with Afghanistan. ${ }^{20}$

On 30 November 2011, Senator Jeff Merkley from Oregon introduced an amendment which required President Barack Obama and the US government to develop plans to expedite the reduction of the US Armed Forces in Afghanistan. The amendment was cosponsored by twenty-eight other senators and passed by the Senate. It sent a clear and strong message to the president by stating that "it is time to bring our men and women home." ${ }^{21}$ On 7 March 2012, twenty-four US Senators sent a letter to President Barack Obama expressing their support for the transition of U.S. forces from a combat role to a training, advising, and assistance role. In the same letter they stated that "it is time to bring our troops home from Afghanistan ... [and] end the large scale counterinsurgency efforts in Afghanistan. ... [W] simply cannot afford more years of elevated troop levels in Afghanistan." 22 
On 20 September 2012, the Republican Senator John McCain from Arizona, who was a proponent of war and promoter of a surge of troops in Afghanistan, led some heavy charges against President Obama. He stated that the Obama administration has mishandled the war in Afghanistan and made the situation very dangerous for the American troops. Therefore, he recommended that the US should withdraw its troops sooner than 2014. He thinks that "all options ought to be considered, including whether ... [the US] has to just withdraw early, rather than have a continued bloodletting that won't succeed." ${ }^{23}$

The public is another element putting pressure on the United States government to end the war and bring the American troops home. The data released by the Rasmussen Report on 7 February 2012 shows that 67 per cent of Americans surveyed said that they would like to end the American combat military engagement in Afghanistan by the middle of next year, while 22 per cent of the respondents were opposed to the idea of ending the military mission. ${ }^{24}$ Another survey was conducted on 13 March 2012 by the USA Today/Gallup Poll. People were asked to respond to the question of whether they want to stick with the 2014 withdrawal plan or to have the troops withdrawn prior to 2014. Twenty-four per cent of the respondents stated that the US should stick to the 2014 timetable. Fifty per cent said that it should speed up the withdrawal, and 21 per cent said that the United States should leave its forces in Afghanistan until the goal is accomplished. ${ }^{25}$

In answering a question in a The New York Times/CBS News Poll 50 per cent of the respondents said that the war in Afghanistan is not a success. Only 39 per cent of the people considered it successful. ${ }^{26}$ Under the joint direction of Anderson Robbins Research and Shaw \& Company Research, Fox News, a conservative and pro-war news channel, conducted interviews between 22 April 2012 and 24 April 2012 to find out how many people in the United State still supported the war in Afghanistan. In responding to the question concerning the situation in Afghanistan, 31 per cent stated they were Extremely Concerned, 49 per cent said they were Very Concerned, 15 per cent said they were Not Very Concerned, 3 per cent said they were Not Concerned At All, and 1 per cent said they Don't Know. When they were asked about the troop withdrawal from Afghanistan, 78 per cent of the people asked said they approve of the withdrawal plan, 16 pe rcent disapproved, and 6 per cent said that they didn't know. ${ }^{27}$

Aside from political and public pressure, the US economy and educational system are in disarray. Gasoline prices have reached $\$ 5.00$ per gallon. The price of food, especially wheat, has doubled in the last two years. Funds are diverted from schools, Social Security, and other public sector programs to finance the war. With unemployment at 7.8 per cent ${ }^{28}$ in September 2012, the US government does not have a valid reason to convince the American people to continue the 
war. Many people have expressed concerns similar to those of Senator Jeff Merkley. "At times of high unemployment, a wave of foreclosures and growing debt, we need to concentrate on nation-building here at home." ${ }^{29}$ The total cost of the war in Afghanistan since 2011 is between \$2.3 trillion and \$2.7 trillion and is still rising ${ }^{30}$. The US total spending on the Afghan war is estimated at $\$ 1.26$ trillion in 2012 and $\$ 967$ billion in 2013. ${ }^{31}$ Considering that the US debt has reached $\$ 16.2$ trillion and is estimated to be $\$ 20.539$ trillion by the end of $2013^{32}$, it will financially be almost impossible to support the war, unless more funds are diverted from education, Social Security, welfare, and other public programs in the United States.

The death toll is of far greater concern than the financial cost. From October 2001 to September 2012, there were 2,130 US military, 1,263 US contractors, 8,665 Afghan National Military and Police, 1,066 other allied troops, 17,400 civilians, 25,000 opposition force, 25 journalists and media workers, and 209 humanitarian/NGO workers ${ }^{33}$ killed in Afghanistan. Considering these facts one has to raise the question, should the war be continued?

Third, since the foreign troops were not able to establish a meaningful level of security and do not have any credible plans as to how to proceed with the war in Afghanistan, the United States and its allies need to recognise the realities and concentrate on real peace negotiations instead of the illusionary path on hand. Some of the coalition partners recognised the need for negotiations long time ago. British Foreign Secretary David Miliband urged political negotiations in his speech to the Massachusetts Institute of Technology in March 2010. He said, "The idea of political engagement with those who would directly or indirectly attack our troops is difficult, but dialogue is not appeasement, and political space is not the same as veto power or domination." ${ }^{34}$ In May 2012 Australian Foreign Minister Bob Carr said that the "Taliban involvement in the coalition would be desirable," and "would make a more sustainable post-2014 ethnic and regional balance in the country." ${ }^{35}$ Peace negotiations are desired by the allies of the United Sates in the present state of affairs.

On the surface there is an ongoing discussion about negotiating with the Taliban, but no serious efforts have been undertaken. Initial and lower level discussions have failed, because both the Taliban and the United States view these negotiations with suspicion and are not sure of each other's sincerity. Instead of hoping to reverse the Taliban momentum to secure a more favorable environment for negotiations, the US and its allies need to end the fighting now if they want peace to come to Afghanistan. Initiatives must be taken toward a political compromise and agreement. This is possible if the following questions can be answered and the practical steps taken. 
1. Does the United Stated recognise the resistance, especially the Taliban, as a legitimate opposition force?

2. Is the United States willing to negotiate with the resistance, especially the Taliban, without any preconditions: Negotiate with them while they are armed and strong?

3. Are the United States and the Karzai government willing to share power with the resistance?

4. Are the Taliban willing to negotiate without demanding that the foreign troops leave before negotiations can take place?

5. Are the Taliban willing to consider accepting the Constitution subject to amendments and modifications?

6. Are the Taliban willing to hold back on their offensives and stop attacking military and civilian facilities?

If the answer to any of the above questions is no, then war will continue. But if the answer is yes, then these questions should be considered.

7. A mechanism of negotiations must be constructed. In order to create such a mechanism, an environment of trust must be created first, in which members of the resistance, especially the Taliban, can feel secure and take part in the negotiations. The Taliban must be given an address either within or outside Afghanistan, where they can be contacted. This will avoid mistakes such as inviting a shopkeeper instead of a Taliban member. The Taliban must feel secure that their participation in negotiations and revealing their identity will not lead to their harassment and arrest. Furthermore, once the scrutiny of the Taliban living in Kabul and other parts of the country ends, the Taliban who are fighting in the front line can be convinced that the United States is serious and honest about negotiations.

Once these conditions are realised, negotiations can take place in three stages. In the first stage, direct negotiations between the United States and the Taliban should take place based on the principles of reconciliation, where long term efforts are made to promote a sustained dialogue. The ultimate objective of this step of negotiations should be to improve relationships and create trust between the United States and the Taliban. In this stage both the US and its allies and the Taliban need to agree to a cease-fire and the US needs to release Taliban prisoners from Guantanamo, Bagram, and other prison facilities and detention centers and remove the names of the Taliban leaders from the blacklist, watch-list or any other lists. Once negotiations are completed, an agreement reached between the two sides, and the outcome approved by the Taliban leadership, especially Mullah Mohammad Omar, the rank and file will follow. 
After the first stage is completed negotiations should move to the second stage, which should include the United States, the Taliban, the Afghan government, Gulbuddin Hekmatyar, and the Haqqani Group (if it is not included as part of the Taliban in the first stage). The fact that the US has formally designated Jalaluddin Haqqani's group as a terrorist organisation, which officially means that the United States will not negotiate with the Haqqani's network, needs to be resolved first. To have meaningful negotiations, both the Haqqani group and Gulbuddin Hekmatyar must be included in the peace negotiations, if not in the first stage, then definitely in the second stage. Since this stage includes negotiations among Afghans, a nonpartisan and independent peace negotiating team, which will arbitrate between the conflicting parties, needs to be put together to start the process of mediation. This team cannot include members of the government, the Taliban, Opposition, political parties affiliated with the government, Jihadi groups, and Jihadi commanders. The objective of this stage of negotiations is to create a process, which would create institutions for sharing power among the conflicting parties. This principle of sharing power would increase the prospects of enduring peace.

The third stage of negotiations should include all of the above mentioned groups plus the Opposition and civil society groups. We have to keep in mind that the first two stages of negotiations will likely be disrupted by certain groups or elements not included in the first two stages. Therefore strategies need to be drafted to reduce their influence and impact, induce them to the peace process, and integrate them in the third stage of negotiations. The international community can help to develop institutional foundations necessary for this process by drawing plans for political process development. This in turn can help the Afghans develop leadership capacities enabling them to work together and bridge the political divide.

The ultimate objectives of negotiations should not only be to settle the differences between the United States, the Taliban, the Afghan government, Hekmatyar, and the Opposition, but to resolve disputes, strengthen the capacities of the communities, develop trust, bring social cohesion, promote inter-group cooperation, and start inter-ethnic dialog. A structured mechanism and forum will need to be put in place to orchestrate and coordinate this type of comprehensive peace process. The definitive goal is to build public consensus around shared values and a shared future.

Once the US has agreed to negotiate with the resistance and negotiations have gone through the three suggested stages, the Organisation of Islamic Cooperation's (OIC) peacekeeping forces could be deployed to Afghanistan. The OIC force shall not include countries that are involved in the current invasion or that were directly or indirectly involved in the political and military conflict in 
Afghanistan since 1978. Even though the past history of OIC is not encouraging in solving conflicts, its presence in Afghanistan will not be perceived negatively, given that it is an entity comprised of Muslim countries.. The OIC can play an important role in facilitating the withdrawal, guaranteeing non-interference, and replacing the current foreign troops in peacekeeping, observing and monitoring forces in Afghanistan. The OIC enforcement power can be effective only if its role is mandated by the UN Security Council. The OIC can be very instrumental in establishing peace, security, and the rule of law in Afghanistan, because the OIC forces will not be seen as foreign troops occupying the country or as undermining and challenging the socio-religious values of Afghanistan. If for some reason, there is disagreement among OIC states and the mandate is vetoed by OIC member state(s), it is recommended that the UN Security Council directly request that Indonesia, Malaysia, and Egypt replace the existing occupying force. Both Indonesia and Egypt have the largest armies in the Muslim world and have experience in conflict resolution. They were both involved either in conflict within their countries or in the region. Throughout history, both countries have had good relationships with Afghanistan. Malaysia on the other hand does not have a large number of armed forces, but it has successfully negotiated a peace agreement between the government of the Philippines and Moro Islamic Liberation front. Many Afghans perceive Malaysia as a model progressive Muslim country. A detailed plan, which is outside the scope of this paper, needs to be developed for implementing the obligations and responsibilities of OIC forces in Afghanistan. But in general the OIC should be mandated to support an Afghan-led and Afghan-owned peace process, maintain peace and security, and monitor political and economic developments.

\section{Impact of the Strategic Partnership Agreement}

A dedicated and intense study is required to understand all aspects and related consequences of the US-Afghanistan Enduring Strategic Partnership Agreement (hereafter referred to as the Agreement). It is not the scope of this paper to undertake such a study, but the research will concentrate on the points most critically relevant to the issue of security and prospects of peace. Afghanistan is a national security challenge for the United States and the neighboring and regional countries. The signing of the Agreement and the presence of American forces in Afghanistan after 2014 have complicated the existing political dimensions in Afghanistan and the region. The main purpose of the Agreement seems to be the protection of the enduring interests of the United States in the region.

With this Agreement the United States wants to maintain effective military control over Afghanistan and intends to monitor the region from Afghanistan. 
The strategic location of Afghanistan would allow the United States to keep a close eye on the military activities and development of the countries in the region. Economically, the Agreement will allow the United States to control the region's oil and gas production, transportation, and distribution, and to undermine the interest of Russia and Iran in developing these resources.

For Afghanistan, the Agreement is broad and general and does not provide specifics on the US financial and military engagement in Afghanistan. It is not clear how the United States wants to highlight and develop the economic and military relationship with Afghanistan without offering information on the amount of economic assistance and the number of military forces to be stationed after 2014. It also does not specify how many bases the Americans will continue to keep. Overall, the agreement does not reflect Afghanistan's economic, political, and security priorities. Therefore, it is merely a maneuver by the United States to legalise its presence, after the other countries' forces leave Afghanistan in 2014. Even though this was already happening since the 2001 invasion, with the signing of the Agreement, the United States has positioned itself as a nimble actor to exploit opportunities in the region and to adjust its policies to the changing economic, political and strategic realities of the region. To better understand the impacts of the Agreement, one needs to analyse it in both its domestic and regional contexts along with its implications.

In Section I of the Agreement it is stated that "Afghanistan and the United States commit to strengthen long-term strategic cooperation in areas of mutual interest including: advancing peace, security, and reconciliation. ${ }^{36}$ In addition, Section III spells out that "the United States affirms that it shall regard with grave concern any external aggression against Afghanistan. The parties shall develop and implement appropriate response, including political, diplomatic, economic, or military measures. ${ }^{{ }^{37}}$ Afghanistan was and still is under attack from Pakistan before and after the signing of the Agreement, but the United States does not deem it necessary to maintain peace and security in the eastern part of Afghanistan or respond in any way to the aforementioned conflict. Section I states that "respect for the sovereignty and equality of states constitutes the foundation of this partnership. Respect for the rule of law, as well as the sound and transparent adherence to Afghanistan's Constitution and all other operative laws, reinforce its foundations. The parties reaffirm their strong commitment to the sovereignty, independence, territorial integrity and national unity of Afghanistan." ${ }^{38}$ Afghanistan is invaded and occupied by the US and its allies. According to international norms, sovereignty and national integrity are diminished when a country is so occupied by forces of another country. When the United States attacks Pashtuns on the other side of the Durand Line, it undermines the territorial integrity of Afghanistan, unless the United States considers Khyber 
Pakhtunkhwa and Balochistan as part of Afghanistan. In the past eleven years, the United States has not acted according to Afghan laws and there is no guarantee it will do so after 2014. Contrary to Afghan and international law, on a regular basis innocent Afghan people are killed or imprisoned by the American forces without any due process. None of the perpetrators from the U.S. military who have committed these crimes are brought to justice. Only Soviet-style staged court proceedings are arranged in the United States where usually the indicted persons are found not guilty. Some which had to be found guilty for political reasons got away with mild sentences.

Section II of the Agreement obligates Afghanistan to protect and promote human rights and democratic values, commit to inclusiveness and pluralism, and forbad Afghanistan from any form of discrimination. The Agreement in this section though fails to talk about US obligations regarding these issues. Section III of the agreement states that "the Parties reaffirm that the presence and operations of the US forces in Afghanistan since 2001 are aimed at defeating al-Qaeda and its affiliates." ${ }^{39}$ As the United States and the world community know, the center of al-Qaeda is located in Pakistan and not in Afghanistan. Osama bin Laden was found and killed in Abbottabad, a military town close to the capital, Islamabad. Pakistan is still considered as a valuable ally in the War on Terrorism. It is not clear how the US intends to fight al-Qaeda and what degree of involvement its forces will have. It is only stated in the agreement that this is going to be decided by future agreements. Presumably the United States will be launching its offensive against al-Qaeda in Pakistan from Afghan soil. Afghanistan will be used as a base to launch an attack on another country, a concern expressed before.

Another conflicting issue in the Agreement is the conduct of the U.S military personnel in Afghanistan. The Agreement reads that "the conduct of ongoing military operations shall continue under existing frameworks." ${ }^{40}$ Under the existing framework, US forces do not abide by any Afghan laws. Any conduct by the US armed forces is decided and executed unilaterally without any check by the Afghan government and armed forces. Since the US armed forces are not bound by Afghan laws, any action the United States takes in Afghanistan cannot be questioned or challenged under the existing frameworks. This contradicts the previous clause.

Financially, it is not clear how the necessary funds would be provided to maintain the Afghan security forces and develop the economy. In Section III it is stated that "beyond 2014, the United States shall seek funds, on a yearly basis, to support the training, equipping, advising, and sustaining the Afghan National Security Forces. ${ }^{{ }^{\prime 1} 1}$ Similarly Section V promises to promote development and provide social and economic assistance without any concrete suggestions and 
financial guarantees as to the approach to be taken. It merely states that "the United States shall seek on a yearly basis, funding for social and economic assistance to Afghanistan." ${ }^{\text {"42 }}$ This indicates that there is no guarantee of funds. With the American economy in decline, resistance to the war in the US, and the funds subject to US Congressional approval, there is no certainty Afghanistan will even receive the 4.1 billion dollars needed to maintain the security forces. This will have dire consequences. Afghanistan's current partial security and limited economic development in the area of consumer commodities are donor driven. If the human and natural resources of the country are not developed, the donordriven and aid-based economy and the fragile political and security structure will likely collapse. The country will experience civil unrest and political and economic strife. The government will lose further support and will eventually collapse.

In the same section of the Agreement, it is stated that the security threats and defense requirements for Afghanistan will be codetermined by the United States. This section clearly challenges Afghanistan's independence and national integrity. Furthermore, Afghanistan is obligated to provide the United States "continued access and use of Afghan facilities through 2014, and beyond . . . to combat al-Qaeda and its affiliates." ${ }^{\prime 3}$ Since al-Qaeda's offices, training centers, and operation facilities are located in Pakistan and the United States wants to destroy these, it would have to do so from Afghanistan, a clear breach of the Agreement.

Another critical element in the same section is the issue of the future presence and operations of the US armed forces in Afghanistan. It is stated that "the nature and scope of the future presence and operation of U.S. forces in Afghanistan, and the related obligations of Afghanistan and the United States, shall be addressed in the Bilateral Security Agreement." ${ }^{\prime 4}$ Two issues arise from this point. First, this section is ambiguous and can be interpreted in any way and taken in any direction. Second, it is not clear what Bilateral Security Agreement the Americans have in mind and for what purposes. If the current Agreement is intended to provide security arrangements for Afghanistan, why is there a need for another agreement? Is there any behind-the-scene work to establish permanent bases in Afghanistan?

Regarding the agreement, neighboring and regional countries are asking many questions and are worried and eager to find out the future US strategy in Afghanistan and in the region. Considering the region's strategic and energy importance, how does the United States envision its presence in Afghanistan? The regional countries have vested interests in Afghanistan and in the region, which are challenged by the future presence of the American forces. The exponential growth of the Asian market is transforming the Asian economies to the global center 
of power in the twenty-first century of global competition. Population growth, economic development, industrialisation, and the demand for more resources are causing a power shift from the industrial West to the developing East. China and India have invested heavily and want to continue to invest in the region to have access to the raw material, minerals and transportation access between Central Asia and the Indian Ocean. Both countries are facing fuel shortages and scarcities in water and other needed resources to maintain their economic progress. Therefore, they are looking outward, especially to Afghanistan and Central Asia. The neighboring countries, along with strategic and economic interests, have ethnic ties and interests in Afghanistan, raising the prospects of proxy war. Similarly Russia and Turkey seek to improve their influence in Afghanistan and in the region. Iran and Pakistan as major suppliers of food products, gas and fuel to Afghanistan, and as major players in resources industries, and as trade and transportation network facilitators in Central Asia, are worried about losing access to Afghanistan. They will face challenges in controlling key access routes and other infrastructure to Central Asia. The Iranian and Pakistani presence is intended to expand their influence in Afghanistan, but the existence of American forces in Afghanistan after 2014 will reduce this influence and undermine Iranian and Pakistani access to resources and trade routes. In general, the agreement not only does not provide any measures of security for Afghanistan, but also raises concerns among the neighboring countries and countries in the region. This may lead to an arms-race, power competition, and domination of the region by regional and world powers.

\section{Conclusion}

The prospects of current and future peace in Afghanistan depend on how the United States, NATO, and ISAF forces conduct their military operations until 2014, and whether the US and its allies are willing to completely withdraw their forces. Leaving forces in place after 2014, even in small numbers, will mean the continuation of conflict and war in Afghanistan. Promised political reforms and economic development, the two most important prerequisites of peace and stability, are not going to take place within the existing government and state structure. The surge in forces and the continuing heavy combat have only intensified violence in Afghanistan, and peace and security are elusive. The US and its allies seem convinced that the military campaign will not defeat the resistance and establish peace, security, and the rule of law, but for political reasons, they continue to drag on with the war. To bring peace and stability to the country, peace negotiations need to take place with the resistance soon. 


\section{Notes}

* Abdul-Qayum Mohmand is Professor of Political Science and Middle East Studies at the University of Utah, where he took his PhD in Middle East Studies and Political Science. His area research includes international security and conflict studies, political violence and terrorism, Middle East government and politics, and Islamic political thought.

1. Isby, Afghanistan: Graveyard of Empires, 55.

2. Ted Weyman, Uranium Contamination of Afghanistan, www.umrc.net. Accessed 15 October 2012.

3. Cordesman, Avoiding Creeping Defeat in Afghanistan, 2.

4. Obama, Remarks by the President in Address to the United Nation on the Way Forward in Afghanistan and Pakistan, 3.

5. Mathew Hoh, Letter of Resignation, 1-2.

6. CSIS and PCR Project, Breaking Point: Measuring Progress in Afghanistan, in Center for Strategic and International Studies Digital Library, http://csis.org/files/media/csis/pubs/070329 breakingpoint.pdf. Accessed September 4, 2009.

7. Cordesman, Avoiding Creeping Defeat in Afghanistan, 2.

8. Ibid.

9. Lovell, "US helicopters in Afghanistan kill 9 children collecting firewood," Digital Journal.

10. Federation of American Scientists, "AH-64 Appache," http://www.fas.org/programs/ssp/man/ uswpns/air/attack/ah64_apache.html, 2-3.

11. My conversation with people in Naranag and Tsawkai, Konar and Ghani Khel, Nangarhar in 2011 and 2012.

12. Cordesman, Ibid., 2.

13. Hadley and Podesta, "The Right Way Out of Afghanistan, 42.

14. SENLIS Afghanistan, Stumbling into Chaos: Afghanistan on the Brink, in The International Council on Security and Development Digital Library http://www.icosgroup.net/modules/reports/ Afghanistan_on_the_brink. Accessed 5 September 2009.

15. Cordesman, Ibid., 7.

16. Hoh, Letter of Resignation, 2.

17. Hoh, Ibid., 2.

18. Bernstein, Negotiating the Insurgency: The Case for Settling Afghanistan's War and Securing "negative'Peace, 27.

19. Southworth, Matt, Powerful Members of Congress Turning Against Afghan War, http://fcnl.org/ blog/2c/ Powerful_members_of_Congress_turning_against_Afghan_war/. Accessed 23 October 2012.

20. Bill Summary \& Status, $112^{\text {th }}$ Congress (2011-2012), H.R. 651, http://www.gpo.gov/fdsys/pkg/ bills-112hr651ih/ pdf/bills-112hr651ih.pdf, Accessed on 23-10-2012.

21. Jeff Merkley, Senate Sends Message To President: Bring U.S. Forces In Afghanistan Home Faster, http://www.merkley.senate.gov/newsroom/press/release/?id=9a8dade3-158a-4a84-a3249be79f33be31, Accessed 22 October 2012.

22. United States Senate, Washington, DC 20501, http://fcnl.org/issues/afghanistan/Baucus_Merkley_ Letter_to_Obama .pdf. Accessed 23 October 2012.

23. Jeremy Herb and Carlo Muñoz, The Hill, http://thehill.com/blogs/defcon-hill/policy-andstrategy/250431-mccain-us-should-consider-leaving-afghanistan-more-quickly

24. Rasmussen reports, 67\% favor Ending U.S. Combat Role in Afghanistan by Next Year, http://www. rasmussenreports.com/public_content/politics/current_events/afghanistan/67_favor_ending_u_s_ combat_role_in_afghanistan_by_next_year, Accessed 23 October 2012.

25. Gallup Politics, In U.S., Half Say U.S. Should Speed Up Afghanistan Withdrawal, http://www. gallup.com/poll/ 153260/half-say-speed-afghanistan-withdrawal.aspx

26. The New York Time/CBS News Poll, http://www.nytimes.com/interactive/2012/03/27/ us/03272012_polling_doc. Accessed 17 October 2012.

27. Fox News Poll, fcnl.org/issues/afghanistan/Fox__Polling_042212.pdf, Accessed 23 October 2012.

28. Bureau of Labor Statistics, "News Release," U.S. Deaprtment of Labor, www.bls.gov. Accessed 20 October 2012. 
29. Jeff Merkley, Bipartisan Amendment Calls for Accelerated Handover in Afghanistan, http:// www.merkley. senate.gov/newsroom/press/release/?id=fab32297-c9bd-4c65-9e2e-ba249dfce810. Accessed 22 October 2012.

30. Cost of War, www.costsofwar.org, Accessed 23 October 2012.

31. Cordessman, "The U.S. Costs of the Afghan War: FY 2002-FY 2013," Center for Strategic \& International Studies, http://csis.org/publication/us-cost-afghan-war-fy2002-fy2013. Accessed 22 October 2012.

32. Debt Clock, http://www.usgovernmentdebt.us

33. Cost of War, www.costsofwar.org. Accessed 23 October 2012.

34. Washington Post, 11 March 2010, http://www.washingtonpost.com/wp-dyn/content/ article/2010/03/10/ AR2010031003888.html. Accessed 18 October 2012.

35. The Australian, http://www.theaustralian.com.au/national-affairs/defence/bob-carr-backs-talibanrole-in-afghanistan/story-e6frg8yo-1226360216437. 18 March 2012.

36. The White House, Enduring Strategic Partnership Agreement between the United States of America and the Islamc Republic of Afghanistan (ESPA), http://www.whitehouse.gov/sites/default/ files/2012.06.01u.s.-afghanistanspasignedtext.pdf, P. 1, Accessed 23 October 2012.

37. ESPA, 5.

38. Ibid., 1-2.

39. ESPA, 2.

40. Ibid., 3 .

41. ESPA, p. 3.

42. Ibid., p. 7.

43. Ibid., 4.

44. Ibid. 